Article

\title{
Prediction of Ground Deformation during Pipe-Jacking Considering Multiple Factors
}

\author{
Dong-Jie Ren ${ }^{1,2}$, Ye-Shuang Xu ${ }^{1,2, *}$, Jack S. Shen ${ }^{3, *}$, Annan Zhou ${ }^{4}$ and Arul Arulrajah ${ }^{3}$ \\ 1 State Key Laboratory of Ocean Engineering, School of Naval Architecture, Ocean, and Civil Engineering, \\ Shanghai Jiao Tong University, Shanghai 200240, China; blink2mm@sjtu.edu.cn \\ 2 Collaborative Innovation Center for Advanced Ship and Deep-Sea Exploration (CISSE), Department of \\ Civil Engineering, Shanghai Jiao Tong University, Shanghai 200240, China \\ 3 Department of Civil and Construction Engineering, Swinburne University of Technology, Victoria 3122, \\ Australia; aarulrajah@swin.edu.au \\ 4 School of Engineering, Royal Melbourne Institute of Technology, Victoria 3001, Australia; \\ annan.zhou@rmit.edu.au \\ * Correspondence: xuyeshuang@sjtu.edu.cn (Y.-S.X.); sshen@swin.edu.au (J.S.S.); \\ Tel.: +86-21-3420-4301 (J.S.S.); Fax: +86-21-6419-1030 (J.S.S.)
}

Received: 11 April 2018; Accepted: 15 June 2018; Published: 27 June 2018

\begin{abstract}
Pipe-jacking is a construction method widely used in pipeline constructions. Prediction of ground deformation induced by pipe-jacking, is important for safety and scheduling purposes. This paper presents an approach to predict ground deformation during pipe-jacking considering following factors: (i) bulkhead additive thrust; (ii) friction on jacking machine; (iii) grouting pressure; and (iv) ground loss. Mindlin's solution was used to calculate the ground deformation induced by bulkhead additive thrust and friction on the jacking machine. The shearing disturbance coefficient was adopted to evaluate the mitigation effect of shearing behavior on ground deformation. Verruijt's solution was used to simulate the effect of grouting pressure. Sagaseta's method was adopted to consider the ground loss induced by over-excavation. Subsequently, a three-dimensional analytical solution for ground deformation induced by pipe-jacking was obtained. A case study based on a pipe-jacking project undertaken in Jiangsu, China was analyzed to validate the proposed approach. The results indicated that the proposed approach was robust and could be implemented for future pipe-jacking projects.
\end{abstract}

Keywords: pipe-jacking; ground deformation; prediction method; grouting pressure

\section{Introduction}

During this period of rapid urbanization in China, many underground facilities are being constructed, e.g., underground commercial centers [1-6], metro systems [7-15], pipelines for water supply [16-23], and communication cables [24-28]. Pipe-jacking, as a trenchless construction technology, has been widely used in these construction projects $[29,30]$. With matured operation technology and high level of automation, pipe-jacking is suitable for application in various geological conditions, such as silty clay, sandy silt and sandy soil [31-38]. However, the geological characteristics of problematic materials such as soft clay is complex [39-51]. During tunneling in soft clay conditions, the jacking process will cause the deformation of surrounding soil, then result in the displacement of nearby buildings [52,53]. To mitigate the environmental disturbance, the prediction of ground deformation is important in pipe-jacking construction.

The essential factor of ground deformation is the ground movement induced by pipe-jacking [54]. Many theoretical analyses have been conducted to study the ground movement. Previous research indicated that ground deformations are influenced by the following factors: (i) ground loss; (ii) pressure 
on excavation face (namely bulkhead additive thrust); (iii) lateral friction on jacking machine; and (iv) grouting process, etc. [55-57]. Due to similar procedures, researchers often prefer the option of shield tunneling for the ground deformation induced by pipe-jacking. Sagaseta [58] assumed that the ground movement is uniform. The consolidation condition of stratum is considered to be undrained. Subsequently, the ground loss was used to calculate the ground deformation in three dimensions. Loganathan and Poulos [59] improved Sagaseta's calculation of ground deformation by considering the radial ground movement as oval-shaped. To analyze the longitudinal ground movement, Liao et al. [60] used Mindlin's solution to calculate ground movement induced by the bulkhead additive thrust and lateral friction during pipe-jacking. However, the grouting process as an important process during pipe-jacking has not been studied in the aforementioned methods [61]. Considering the grouting process, the lateral friction between pipe segments and surrounding soils will be reduced due to the existence of slurry [17]. Furthermore, the grouting pressure will apply additional stresses on the surrounding soils and result in ground movement [62]. In addition, numerical methods are widely used to simulate the ground movement [63]. Shimada et al. [64] found that performance of mud slurry plays an important role in the pushing process and that suitable slurry pressure is proved to be necessary for the stability of surrounding soils by numerical simulation $[65,66]$.

This paper proposes a new approach to predict ground deformation induced by pipe-jacking construction. The grouting process is considered to be a new factor for the ground movement during pipe-jacking. To achieve this goal, Verruijt's solution will be used to calculate the ground movement induced by the grouting process. A case study of pipe-jacking construction will be analyzed to verify the proposed method.

\section{Review of Existing Methods}

Verruijt [67] has proposed equations for calculating the ground deformation induced by tunneling. In Verruijt's solution, the ground was considered as an elastic half-plane with a circular cavity. Figure 1 shows the illustration of a case with uniform stress applied at the tunnel boundary. $\sigma_{\mathrm{p}}$ is the stress at the interface of the plastic and elastic zones, $R_{\mathrm{p}}$ is the external radius of the plastic zone, and $h$ is the depth of tunnel center. After dividing the deformation of tunnel boundary into a uniform radial displacement and a downward displacement, the equations can be deduced by complex variables, as listed as follows:

$$
\begin{aligned}
& u_{\mathrm{xA}}=\operatorname{Re}\left(\frac{1+\mu}{E}\left((3-4 v) \phi(Z)-Z \overline{\phi^{\prime}(Z)}-\overline{\psi(Z)}\right)\right) \\
& u_{\mathrm{yA}}=\operatorname{Im}\left(\frac{1+\mu}{E}\left((3-4 v) \phi(Z)-Z \overline{\phi^{\prime}(Z)}-\overline{\psi(Z)}\right)\right)
\end{aligned}
$$

where Re and Im means taking the real and imaginary parts respectively; $u_{x A}$ is the displacement of point $A$ at $x$ direction; $u_{y A}$ is the displacement of point $A$ at $y$ direction; $u$ is Poisson's ratio; $E$ is Young's modulus; $Z=x+i y ; \varphi(Z)$ and $\Psi(Z)$ are analytic functions, and can be determined from following equations:

$$
\begin{gathered}
\phi(Z)=M_{d}\left(-2 i\left(1+\xi^{2}\right)+2 i \frac{Z\left(1+\xi^{2}\right)+i h\left(1-\xi^{2}\right)}{Z\left(1+\xi^{2}\right)-i h\left(1-\xi^{2}\right)}+2 i \xi^{2} \frac{Z\left(1+\xi^{2}\right)-i h\left(1-\xi^{2}\right)}{Z\left(1+\xi^{2}\right)+i h\left(1-\xi^{2}\right)}\right) \\
\psi(Z)=M_{d}\left(-3 i\left(1+\xi^{2}\right)+2 i \xi^{2} \frac{Z\left(1+\xi^{2}\right)+i h\left(1-\xi^{2}\right)}{Z\left(1+\xi^{2}\right)-i h\left(1-\xi^{2}\right)}+i\left(\frac{Z\left(1+\xi^{2}\right)+i h\left(1-\tilde{\xi}^{2}\right)}{Z\left(1+\xi^{2}\right)-i h\left(1-\tilde{\xi}^{2}\right)}\right)^{2}\right. \\
\left.+2 i \frac{Z\left(1+\xi^{2}\right)-i h\left(1-\xi^{2}\right)}{Z\left(1+\xi^{2}\right)+i h\left(1-\xi^{2}\right)}+i \xi^{2}\left(\frac{Z\left(1+\xi^{2}\right)-i h\left(1-\xi^{2}\right)}{Z\left(1+\xi^{2}\right)+i h\left(1-\tilde{\xi}^{2}\right)}\right)^{2}\right) \\
M_{d}=-\frac{\xi^{2} \sigma_{\mathrm{p}} h}{\left(1-\xi^{2}\right)\left(1-\xi^{4}\right)}
\end{gathered}
$$




$$
\xi=\frac{h-\sqrt{h^{2}-R_{\mathrm{p}}^{2}}}{R_{\mathrm{p}}}
$$

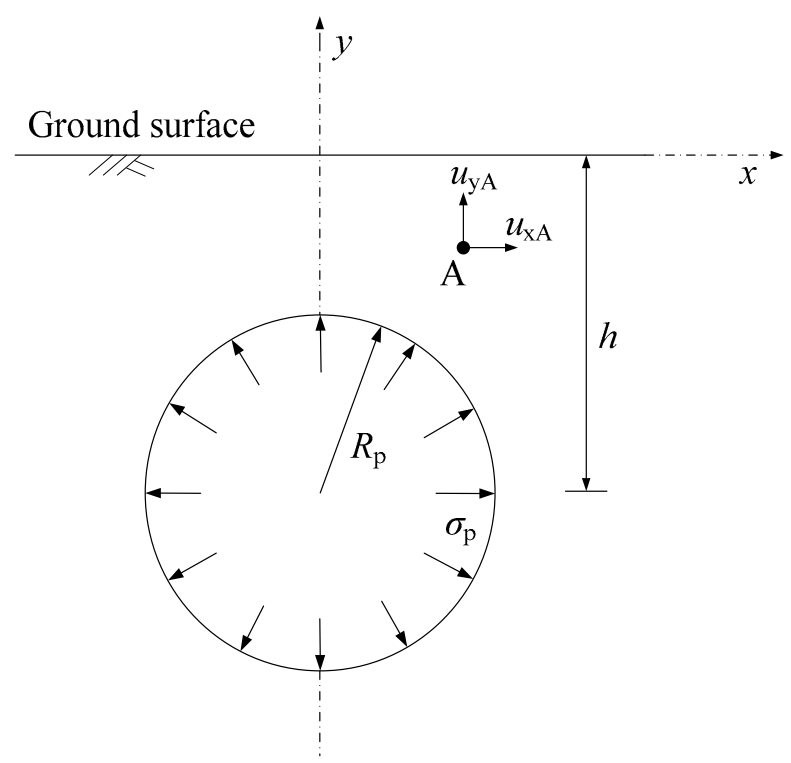

Figure 1. Illustration of a case with uniform stress applied at tunnel boundary (recreated based on Shen et al. [11], Wang et al. [68]).

For three dimensional elastic scenarios, Mindlin [69] had proposed solutions for deformation in a homogenous isotropic solid. Wei [61] used Mindlin's solution to calculate the ground movement induced by the bulkhead additive thrust and the friction between the jacking machine and surrounding soils at arbitrary point $B(x, y, z)$. Figure 2 shows the calculation schematic of Mindlin's solution. $x$ is the horizontal distance from the excavation face of the point $B$ along the jacking direction, $y$ is the lateral distance from the jacking axis to the point $B, z$ is the depth of the point $B, h$ is the depth of jacking machine centerline.

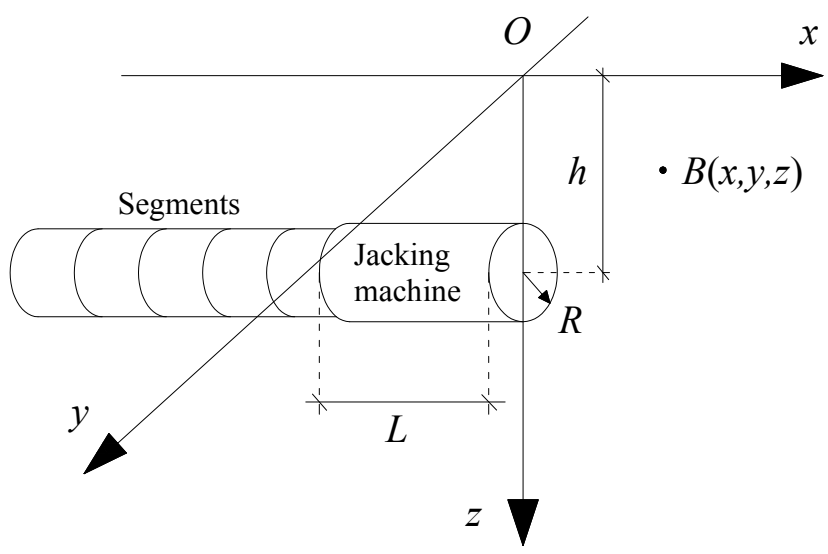

Figure 2. Calculation schematic of Mindlin's solution. 
The equations for calculating the ground movement due to the bulkhead additive forces are listed as follows:

$$
\begin{gathered}
u_{1}=\frac{P}{16 \pi G(1-\mu)} \int_{0}^{2 \pi} \int_{0}^{R}\left[\frac{3-4 \mu}{M_{1}}+\frac{1}{N_{1}}+\frac{x^{2}}{M_{1}^{3}}+\frac{(3-4 \mu) x^{2}}{N_{1}^{3}}+\frac{2 z c_{1}}{N_{1}^{3}}\left(1-\frac{3 x^{2}}{N_{1}^{2}}\right)\right. \\
\left.+\frac{4(1-\mu)(1-2 \mu)}{N_{1}+z+c_{1}}\left(1-\frac{x^{2}}{N_{1}\left(N_{1}+z+c_{1}\right)}\right)\right] r d r d \theta \\
v_{1}=\frac{P x}{16 \pi G(1-\mu)} \int_{0}^{2 \pi} \int_{0}^{R}(y+r \cos \theta)\left[\frac{1}{M_{1}^{3}}+\frac{3-4 \mu}{N_{1}^{3}}-\frac{6 z c_{1}}{N_{1}^{5}}-\frac{4(1-\mu)(1-2 \mu)}{N_{1}\left(N_{1}+z+c_{1}\right)^{2}}\right] r d r d \theta \\
w_{1}=\frac{P x}{16 \pi G(1-\mu)} \int_{0}^{2 \pi} \int_{0}^{R}\left[\frac{z-c_{1}}{M_{1}^{3}}+\frac{(3-4 \mu)\left(z-c_{1}\right)}{N_{1}^{3}}-\frac{6 z c_{1}\left(z+c_{1}\right)}{N_{1}^{5}}+\frac{4(1-\mu)(1-2 \mu)}{N_{1}\left(N_{1}+z+c_{1}\right)}\right] r d r d \theta
\end{gathered}
$$

where, $u_{1}$ is the movement of point $B$ in $x$ axis direction; $v_{1}$ is the movement of point $B$ in $y$ axis direction; $w_{1}$ is the movement of point $B$ in $z$ axis direction; $P$ is the bulkhead additive thrust; $G$ is the shear modulus of soil; $\mu$ is Poisson's ratio. $M_{1}$ and $N_{1}$ can be expressed as:

$$
\begin{gathered}
M_{1}=\sqrt{x^{2}+(y+R \cos \theta)^{2}+\left(z-c_{1}\right)^{2}} \\
N_{1}=\sqrt{x^{2}+(y+R \cos \theta)^{2}+\left(z+c_{1}\right)^{2}} \\
c_{1}=h-r \sin \theta
\end{gathered}
$$

The equations for ground movement induced by the friction between the jacking machine and surrounding soils are listed as follows:

$$
\begin{gathered}
u_{2}=\frac{f R}{16 \pi G(1-\mu)} \int_{0}^{2 \pi} \int_{0}^{L}\left[\frac{3-4 \mu}{M_{2}}+\frac{1}{N_{2}}+\frac{(x+l)^{2}}{M_{2}^{3}}+\frac{(3-4 \mu)(x+l)^{2}}{N_{2}^{3}}+\frac{2 z c_{2}}{N_{2}^{3}} .\right. \\
\left.\left(1-\frac{3(x+l)^{2}}{N_{2}^{2}}\right)+\frac{4(1-\mu)(1-2 \mu)}{N_{2}+z+c_{2}}\left(1-\frac{(x+l)^{2}}{N_{2}\left(N_{2}+z+c_{2}\right)}\right)\right] d l d \theta \\
v_{2}=\frac{f R}{16 \pi G(1-\mu)} \int_{0}^{2 \pi} \int_{0}^{L}(x+l)(y+R \cos \theta)\left[\frac{1}{M_{2}^{3}}+\frac{3-4 \mu}{N_{2}^{3}}-\frac{6 z c_{2}}{N_{2}^{5}}-\frac{4(1-\mu)(1-2 \mu)}{N_{2}\left(N_{2}+z+c_{2}\right)^{2}}\right] d l d \theta \\
w_{2}=\frac{f R}{16 \pi G(1-\mu)} \int_{0}^{2 \pi} \int_{0}^{L}(x+l)\left[\frac{z-c_{2}}{M_{2}^{3}}+\frac{(3-4 \mu)\left(z-c_{2}\right)}{N_{2}^{3}}-\frac{6 z c_{2}\left(z+c_{2}\right)}{N_{2}^{5}}+\frac{4(1-\mu)(1-2 \mu)}{N_{2}\left(N_{2}+z+c_{2}\right)}\right] d l d \theta
\end{gathered}
$$

where, $u_{2}\left(v_{2}, w_{2}\right)$ is the ground movement along the $x(y, z)$ axis caused by friction on the jacking machine. $f$ is the average friction between the jacking machine and surrounding soils. $M_{2}$ and $\mathrm{N}_{2}$ can be expressed as:

$$
\begin{gathered}
M_{2}=\sqrt{(x+l)^{2}+(y+R \cos \theta)^{2}+\left(z-c_{2}\right)^{2}} \\
N_{2}=\sqrt{(x+l)^{2}+(y+R \cos \theta)^{2}+\left(z+c_{2}\right)^{2}} \\
c_{2}=h-R \sin \theta
\end{gathered}
$$

where, $L$ is the length of the jacking machine, $R$ is the external radius of the jacking machine.

The aforementioned solutions were used to calculate ground movements due to the bulkhead additive thrust and the frictions between the jacking machine and surrounding soils. Wei [61] has also proposed solutions for the evaluation of the friction between jacking segments and surrounding soils. However, because of the lubrication effect induced by the grouting process, the friction between jacking segments and surrounding soils is very small. On the other hand, Kasper and Meschke [65] reported that the grouting process will apply additional pressure on surrounding soils, which may cause ground 
movement and finally affect the ground deformation. Therefore, a new method is required to improve the prediction of ground deformation induced by pipe-jacking construction.

\section{Methodology}

\subsection{Assumptions}

As the excavation process is complex, the superposition method with multiple factors is widely used for the calculation of ground deformation [61,70]. In this study, ground movements caused by bulkhead additive thrust, friction on jacking machine, grouting pressure, and ground loss were calculated separately and subsequently combined. To simplify the theoretical analysis, the following assumptions will be used: (1) the object is a three-dimensional homogenous isotropic elasticity with the jacking machine and segments; (2) the ground movement is caused by the construction of pipe-jacking rather than by change in the volume of the soil; (3) the ground loss is uniform along the tunnel axis and the profile is considered to be oval-shaped; (4) the grouting pressure is uniform along radial direction and tunnel axis; (5) the effect of grouting on ground loss was ignored. Based on these assumptions, Figure 3 shows the schematic of pipe-jacking and the mechanical condition of surrounding soils. $R_{\mathrm{S}}$ is the external radius of segment.
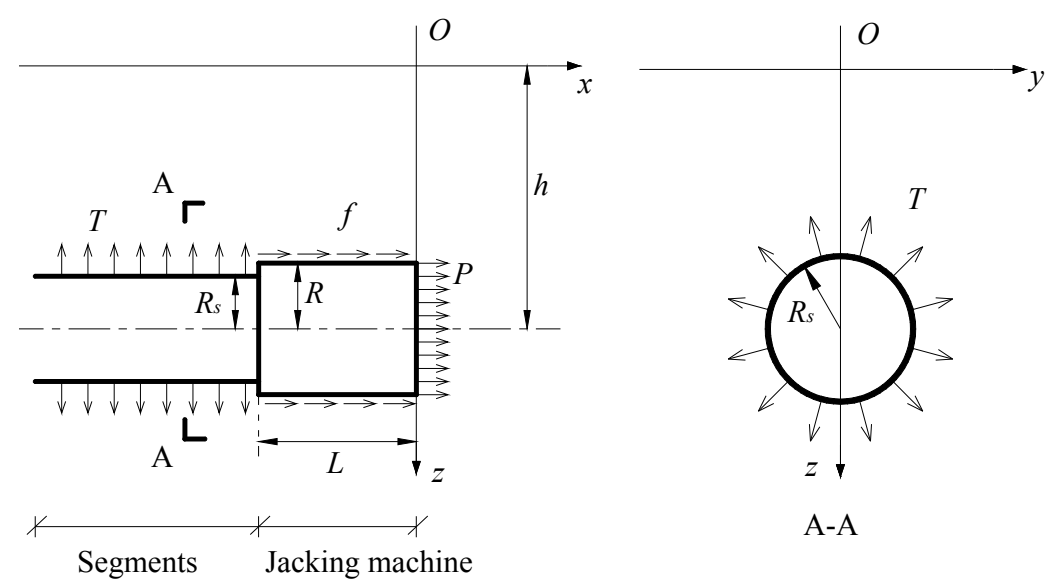

A-A

Figure 3. Calculation schematic of Mindlin's solution.

\subsection{Influence Factors}

\subsubsection{Bulkhead Additive Thrust and Friction on Jacking Machine}

In front of the jacking machine, the condition of the surrounding soils can be further divided into the shearing region and the compression region, as shown in Figure 4. Equations (7)-(9) based on Mindlin's solution only considered the normal compression induced by the bulkhead additive thrust. The shearing behavior of soils at the boundary between region $i$ and region $i i i$ has not been considered. During the compression of soil in front of the jacking machine, the shearing behavior will apply a friction force against the bulkhead additive thrust, then mitigate the ground movement. The same phenomenon also exists between the jacking machine and surrounding soils. The surrounding soils will reach the failure criterion becoming soft under the shearing effect. The smaller friction coefficient of the softened surrounding soils will decrease the ground movement induced by the friction force. The modified ground movement caused by the bulkhead additive thrust and friction on jacking machine can be expressed as:

$$
\begin{aligned}
& u_{1}{ }^{\prime}=\alpha_{p} u_{1} \\
& u_{2}{ }^{\prime}=\alpha_{f} u_{2}
\end{aligned}
$$


where, $\alpha_{p}$ is the shearing disturbance coefficient caused by bulkhead additive thrust, and $\alpha_{f}$ is the shearing disturbance coefficient caused by friction, which are supposed to have a relationship with the cohesion of the construction soil layer and the bulkhead additive thrust or the friction between jacking machine and surrounding soils. The empirical equations for these two coefficients can be expressed as:

$$
\begin{aligned}
& \alpha_{p}=\frac{c}{P} \\
& \alpha_{f}=\frac{c}{f}
\end{aligned}
$$

where, $c$ is the cohesion of the construction soil layer.

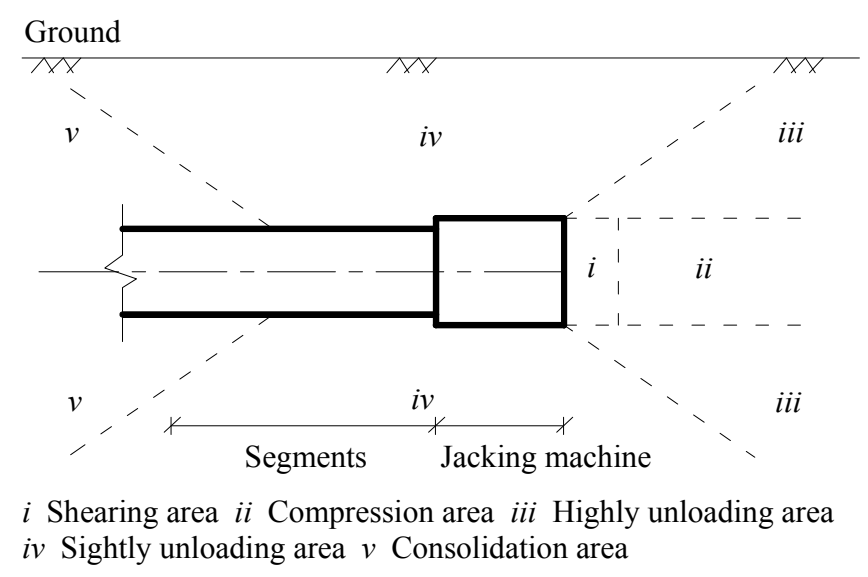

Figure 4. Districts of surrounding soils under the disturbance of pipe-jacking.

\subsubsection{Grouting Pressure}

The ground movement caused by grouting pressure will be firstly calculated in the sectional direction then overlaid along the penetrating direction. In the sectional direction, the ground movement induced by grouting pressure is assumed to be a cavity expansion process in an elastic half-plane. Verruijt [66] has given equations for calculating the deformation with uniform stress applied at the cavity boundary. The solution uses the complex variables to calculate the ground movement. The displacement of a picked point should satisfy the following equation:

$$
\frac{E}{1+\mu}(v-i w)=\frac{3-\mu}{1+\mu} \varphi(Z)-Z \overline{\varphi^{\prime}(Z)}-\overline{\psi(Z)}=S(y, z)
$$

Then Verruijt solution can be expressed as:

$$
\begin{gathered}
\varphi(Z)=i M_{T}\left[-2\left(1+\alpha^{2}\right)+\frac{2(Z-t)}{Z+t}+\frac{2 \alpha^{2}(Z+t)}{Z-t}\right] \\
\psi(Z)=i M_{T}\left[-3\left(1+\alpha^{2}\right)+\frac{2 \alpha^{2}(Z-t)}{Z+t}+\frac{2(Z+t)}{Z-t}+\frac{\alpha^{2}(Z+t)^{2}}{(Z-t)^{2}}\right] \\
\alpha=\frac{h-\sqrt{h^{2}-R_{s}^{2}}}{R_{s}} \\
t=-i h \frac{1-\alpha^{2}}{1+\alpha^{2}} \\
M_{T}=-\frac{\alpha^{2} T h}{\left(1-\alpha^{2}\right)\left(1-\alpha^{4}\right)}
\end{gathered}
$$


where, $T$ is the grouting pressure, which can be calculated by:

$$
T=\frac{n T_{0} d^{2}}{4\left(R^{2}-R_{s}^{2}\right)}
$$

where, $n$ is the proportion of grouting volume and gap volume, $T_{0}$ is the grouting pressure of jetting machine, and $d$ is the diameter of grouting pipeline. This equation determines the proportion of these two pressures by the sectional area. The permeation of slurry during the grouting process is also considered by the proportion of grouting volume and gap volume.

Along the penetrating direction, the Boussinesq solution is used to overlay the ground movement in the sectional direction. Figure 5 shows overlaying coefficients in the sectional direction $(m)$ and penetrating direction $(n)$. Then the ground movement caused by grouting pressure can be expressed as:

$$
\begin{gathered}
u_{3}=\frac{1+\mu}{E}|S(y, z)| \times(1-\mu) \exp \left[-0.5(x+L)^{2}\right] \\
v_{3}=\frac{1+\mu}{E} \operatorname{Re}[S(y, z)] \times\left\{1-\frac{1}{1+\exp [-(x+L)]}\right\} \\
w_{3}=\frac{1+\mu}{E} \operatorname{Im}[S(y, z)] \times\left\{1-\frac{1}{1+\exp [-(x+L)]}\right\}
\end{gathered}
$$

where, $u_{3}\left(v_{3}, w_{3}\right)$ is the ground movement along the $x(y, z)$ axis caused by grouting pressure.

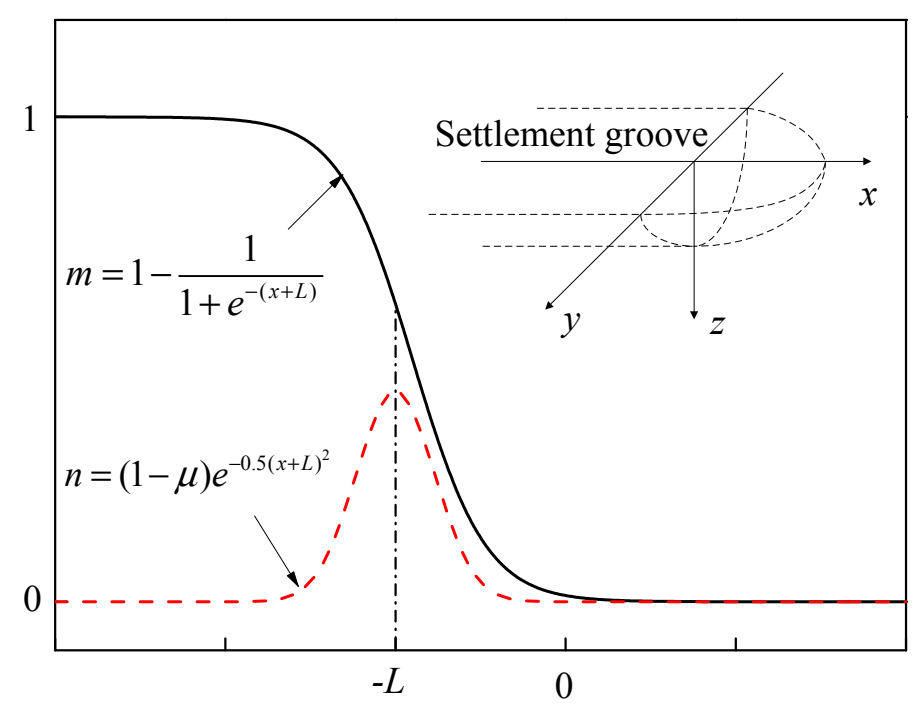

Figure 5. Overlaying coefficients in section direction and penetrating direction.

\subsubsection{Ground Loss}

Sagaseta [58] presented an analytical solution for calculating the ground surface movement in the isotropic homogeneous and incompressible ground condition. The equations are as follows:

$$
\begin{gathered}
u_{s}=-\frac{V}{2 \pi} \frac{1}{\left(x^{2}+y^{2}+h^{2}\right)^{1 / 2}} \\
v_{s}=-\frac{V}{2 \pi} \frac{y}{y^{2}+h^{2}}\left[1-\frac{x}{\left(x^{2}+y^{2}+h^{2}\right)^{1 / 2}}\right] \\
w_{s}=\frac{V}{2 \pi} \frac{h}{y^{2}+h^{2}}\left[1-\frac{x}{\left(x^{2}+y^{2}+h^{2}\right)^{1 / 2}}\right]
\end{gathered}
$$


where, $u_{s}\left(v_{s}, w_{s}\right)$ is the ground movement along $x(y, z)$ axis in Sagaseta solution, $V$ is the ground loss per unit length $\left(\mathrm{m}^{3} / \mathrm{m}\right)$.

Sagaseta's solution can be used as the vertical displacement, whereas the lateral and longitudinal deformations of the inner soil are not satisfied with the measured ones. Finding that the ground loss due to lining deflection and lining gap are not uniform, Loganathan and Poulos [59] proposed the gap should be oval shaped and gave the equation for calculating the equivalent ground loss, which is shown as follows:

$$
\begin{gathered}
V^{\prime}=V \times \exp \left[-\frac{1.38 y^{2}}{(h+R)^{2}}-\frac{0.69 z^{2}}{h^{2}}\right] \\
V=\pi R^{2} \eta
\end{gathered}
$$

where, $\eta$ is the empirical coefficient, which has the relationship with the pipe-jacking face and the geotechnical conditions, for instance $\eta$ is $0.5 \sim 2.5 \%$ for silty soil layers.

Thus, considering the oval shaped ground movement and the Poisson's ratio for different soils, we modified Sagaseta's solution and have proposed the following equations:

$$
\begin{gathered}
u_{4}=-\frac{2(1-\mu) V^{\prime}}{\pi} \frac{1}{\sqrt{x^{2}+y^{2}+h^{2}}} \\
v_{4}=-\frac{2(1-\mu) V^{\prime}}{\pi} \frac{y}{y^{2}+h^{2}}\left(1-\frac{x}{\sqrt{x^{2}+y^{2}+h^{2}}}\right) \\
w_{4}=\frac{2(1-\mu) V^{\prime}}{\pi} \frac{h}{y^{2}+h^{2}}\left(1-\frac{x}{\sqrt{x^{2}+y^{2}+h^{2}}}\right)
\end{gathered}
$$

where, $u_{4}\left(v_{4}, w_{4}\right)$ is the ground movement along the $x(y, z)$ axis caused by ground loss.

\subsection{Results of Total Ground Deformation}

The ground deformation induced by the aforementioned factors is a three-dimensional issue. By ignoring the interaction among these four factors, the overall ground movement can be determined by overlaying four parts of ground movements induced by each factor:

$$
\begin{gathered}
u=u_{1}{ }^{\prime}+u_{2}{ }^{\prime}+u_{3}+u_{4} \\
v=v_{1}+v_{2}+v_{3}+v_{4} \\
w=w_{1}+w_{2}+w_{3}+w_{4}
\end{gathered}
$$

Although the analytical process and the equations are complex, the specific calculation can be conducted by MATLAB with a high efficiency.

\section{Application to Case Study}

\subsection{Project Description}

To validate the proposed approach, a field pipe-jacking project of water-conveying tunnels was introduced. Figure 6 depicts the location of pipe-jacking construction site. The field site is located at the junction of Huangxiang River and Guan River, in the northern Jiangsu province. Four jacking pipes cross through $450 \mathrm{~m}$ under Guan River. The interval between the two adjacent jacking pipes was about $9 \mathrm{~m}$. The diameter of the jacking machine is $4200 \mathrm{~mm}$, while the external diameter of the pipe segment is $4160 \mathrm{~mm}$. The synchronous grouting with pressure ranging from 0.10 to $0.15 \mathrm{MPa}$ is conducted to fill the gap and reduce the friction between pipe segments and surrounding soils. 


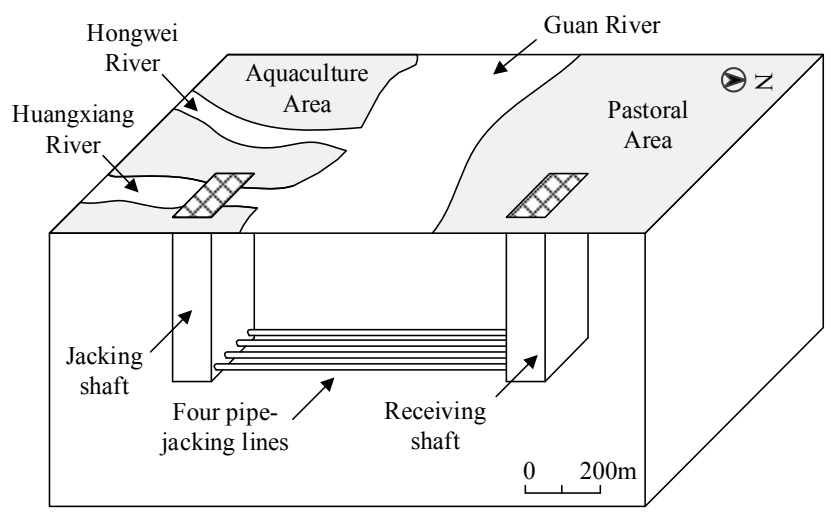

Figure 6. Location of pipe-jacking construction site.

The ground consisted of various soil layers, including backfill, clay, stiff clay, silty clay, cemented silty sand, and silty sand. Figure 7 shows the distribution of soil layers. The average depth of the pipe-jacking is about $18.9 \mathrm{~m}$ below the ground surface. The jacking region is mainly in silty clay, cemented silty sand, and silty sand. These layers contain irregular cementitious sand particles, which may cause the blocking in slurry pipelines and difficulties in excavation process. Figure 8 shows the soil profile and the soil properties in the construction site. The natural water content of these soils in the pipe-jacking zone ranges from $25 \%$ to $28 \%$ and the compression index varies between 0.04 and 0.16 .

During the pipe-jacking process, layered settlement gauges were employed to observe the ground deformation. Figure 9 illustrates the plane view of layered settlement gauges. The distance between two adjacent layered settlements is $4.5 \mathrm{~m}$. The distance between the gauges and the south jacking shaft is $60 \mathrm{~m}$. Figure 9 also depicts the sectional view of layered settlement gauges. The vertical depth of the gauge is $12.5 \mathrm{~m}$ under the ground. Three layered settlement gauges combine into a monitoring group. As Line 1 and Line 3 are constructed prior to Line 2 and Line 4, ground settlements caused by Line 2 and Line 4 have been disturbed by those caused by Line 1 and Line 3 . Therefore, only two monitoring groups were employed to record the ground settlement of Line 1 and Line 3. The recording period starts at the initial penetration of pipe-jacking, ending when the jacking machine is $30 \mathrm{~m}$ away from the monitoring point.

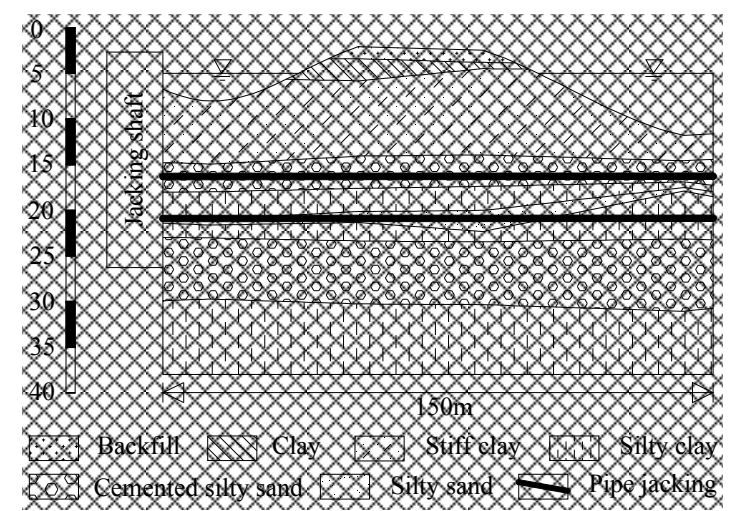

Figure 7. Distribution of soil layers in construction site. 


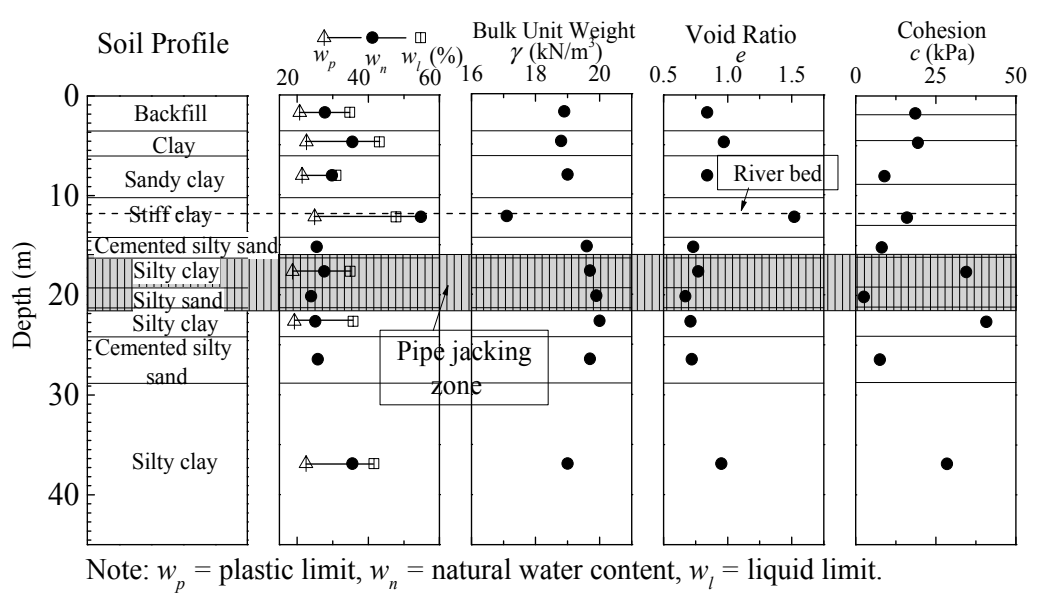

Figure 8. Geotechnical profiles and soil properties of the construction site (based on Shen et al. [71]).

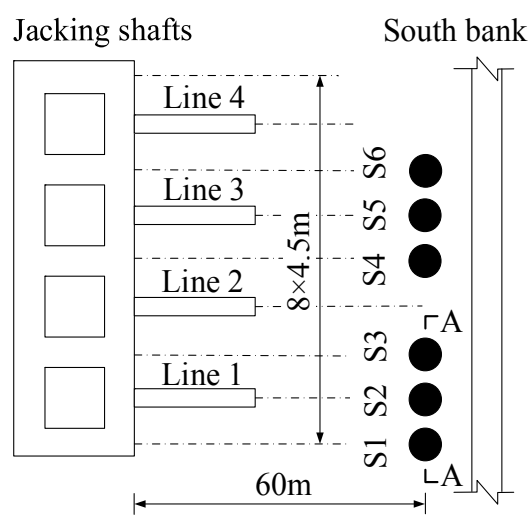

- Layered settlement gauge (S)

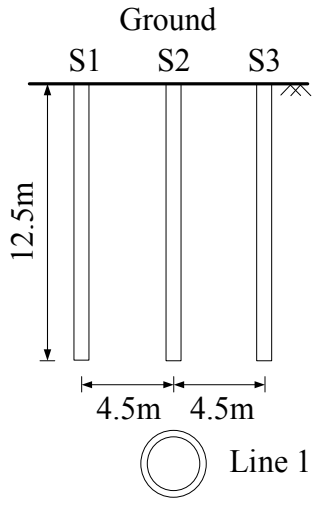

A-A

Figure 9. Location and vertical distribution of layered settlement gauges.

\subsection{Validation}

During the construction of Line 1 and Line 3, parameters for the calculation of ground movement have been listed in Table 1. The in situ soil stress in the tunnel face is about 0.4 MPa. The pressure in Table 1 is significant for the stability of the tunnel face. Based on the monitored ground settlements in different depths, the vertical strain can be determined. The average strain level is about $0.1 \sim 0.2 \%$, which confirms to the small strain condition. Then, $G$ is defined as the weighted average value of small strain stiffness. Compared to similar case studies, the adopted value is reasonable [72,73]. Based on these parameters, the ground deformation can be calculated by the proposed method. The ground settlement is the result of ground deformation at the ground surface. As the ground movements in $x$ axis direction and $\mathrm{y}$ direction are difficult to be monitored in the underground condition, the ground settlements at different depth are used to validate the effectiveness of the proposed method. The Attewell method [74] can compute the settlement along the tunnel path by using the cumulative curve on the results determined by the Peck method. The equation can be expressed as:

$$
S(y)=\frac{V}{\sqrt{2 \pi} i}\left[\Phi\left(\frac{y-y_{i}}{i}\right)-\Phi\left(\frac{y-y_{f}}{i}\right)\right]
$$

where, $i$ is the coefficient of width of ground settlement groove, $\Phi$ is the integration of Gaussian distribution, $y_{i}$ is the distance of pipe-jacking, $y_{f}$ is the distance from tunnel face to the original point. Wei et al.'s method [61] are used to compare the prediction effectiveness. Peck's method that is usually used in shield tunneling, only considered the effect of ground loss on the ground settlement. Wei et al.'s 
method is a general empirical model based on Peck, Sagaseta, Loganathan and Poulos's researches. However, the effect of grouting pressure is ignored in Wei et al.'s method.

Table 1. Construction parameters for Line 1 and Line 3.

\begin{tabular}{cccccccccc}
\hline $\boldsymbol{P}(\mathrm{MPa})$ & $\boldsymbol{f}(\mathbf{M P a})$ & $\boldsymbol{T}(\mathbf{M P a})$ & $\boldsymbol{\eta}(\boldsymbol{\%})$ & $\mu$ & $G(\mathbf{M P a})$ & $\boldsymbol{h}(\mathbf{m})$ & $\boldsymbol{L}(\mathrm{m})$ & $\boldsymbol{R}(\mathrm{m})$ & $\boldsymbol{R}_{\boldsymbol{s}}(\mathrm{m})$ \\
\hline 0.30 & 0.24 & 0.08 & 2 & 0.31 & 2.4 & 18.9 & 5 & 2.1 & 2.08 \\
\hline
\end{tabular}

Figure 10 shows the ground settlements of the monitoring points right above Line 1 and Line 3 . Generally, the proposed method has a good consistency with the field results, as compared to the field data and the other two methods. In theoretical calculations, the jacking process will cause an upheaval of the ground surface before the jacking machine arrives at the monitoring point. However, the field data indicated that the upheaval is small in Line 1. For Line 3, the ground surface indicated evidence of settlement. The reason for this is that before the arrival of the jacking machine, the permeation of underground water had caused consolidation behavior. When the jacking machine arrives at the monitoring point, both the calculated results and field observations shows a sharp decrease in ground settlement. The final settlement calculated by the proposed method is the smallest among the calculated results as only the proposed method considers the effect of grouting process. The slurry grouting can apply pressure on the interface, expanding surrounding soils, then mitigating ground settlement. The difference between calculated settlements and field data may attribute to the mutual disturbance during the construction of Line 1 and Line 3.

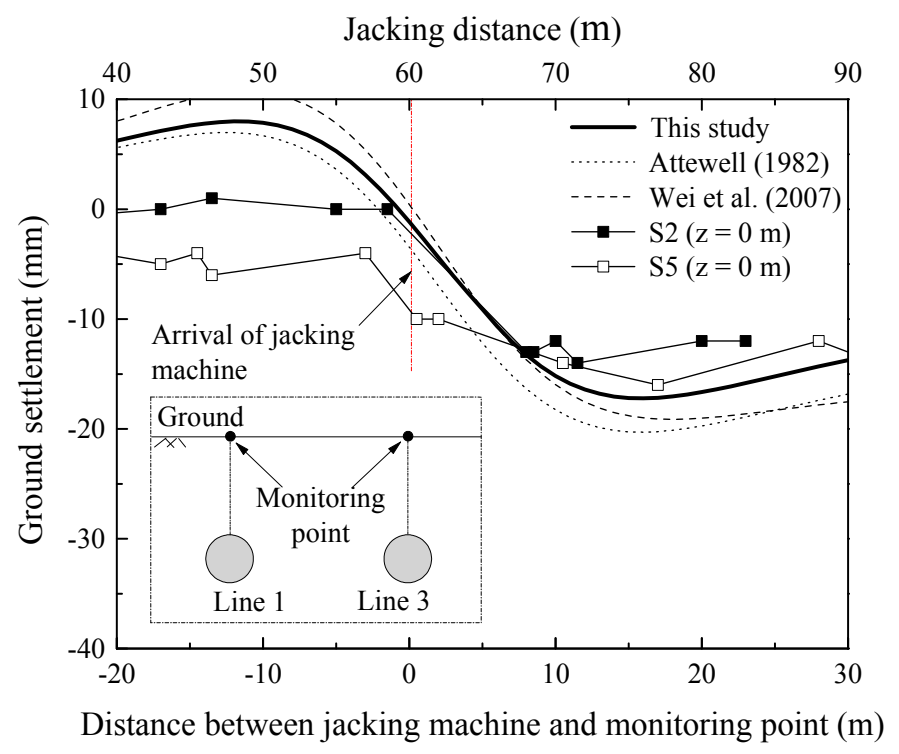

Figure 10. Ground surface settlements above Line 1 and Line 3.

Figure 11 shows the proportions of the single factors as bulkhead thrust force, friction, grouting pressure and ground loss on the overall ground settlement. The main ground settlement is caused by the ground loss. The slurry grouting mitigates the ground settlement effectively after the jacking machine passing through the monitoring point. The ground movements induced by the bulkhead additive thrust and the friction on jacking machine were much smaller than that of ground loss. 


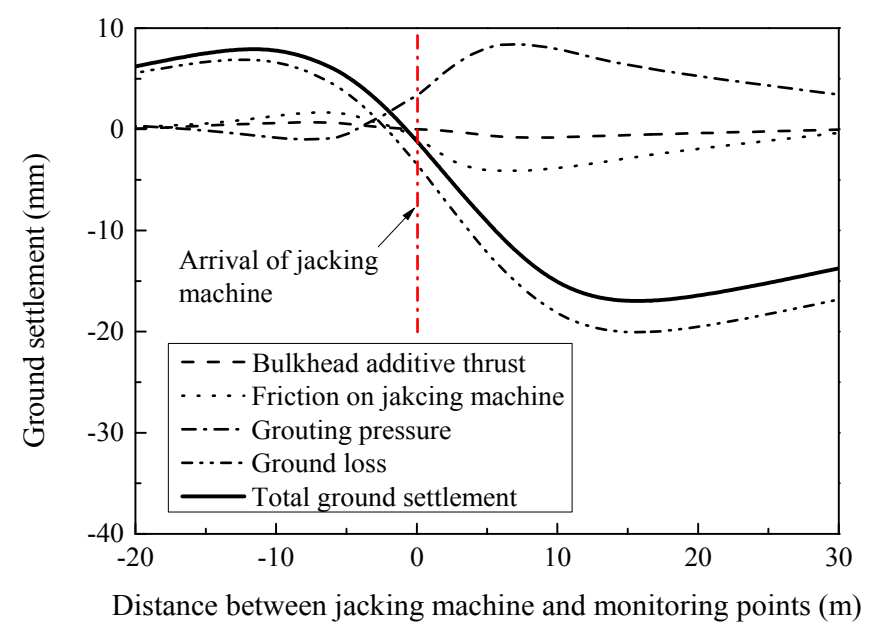

Figure 11. Proportions of influence factors on overall ground settlement.

Figure 12 shows the settlements at the depth of $7.4 \mathrm{~m}$ above Line 1 and Line 3. The proposed method matches better to the settlement above Line 1. The field data show that the underground movement is more irregular than the ground surface settlement. It indicates that the disturbance caused by pipe-jacking is more obvious in the underground region. The influence of the grouting pressure on ground movement will reduce with increasing distances. The predicted results show a good consistency to the monitored results after the jacking machine crossed through the monitoring point. Considering the grouting pressure in the proposed method leads to an improvement in prediction effectiveness, as compared to the other two methods.

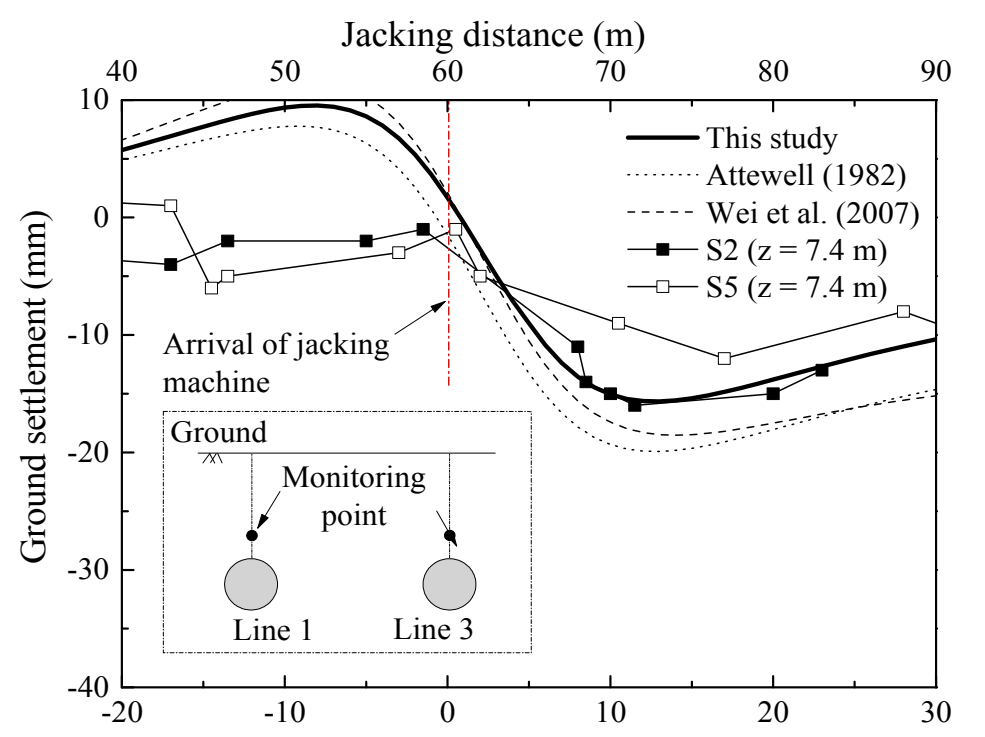

Distance between jacking machine and monitoring points (m)

Figure 12. Ground settlements at depth of $7.4 \mathrm{~m}$ below surface.

Figure 13 shows the ground surface settlements adjacent to Line 1 and Line 3 . The predicted results are closer to the results from the two middle monitoring points. The field data indicate that the ground settlements between the pipe-jacking (S3 and S4) is larger than those at the outer sides. As the middle region is disturbed by the construction of Line 1 and Line 3, the settlement phenomenon can be explained by the superposition theory. The method in this study is proposed based on the single line of pipe-jacking and has not considered the settlements caused by adjacent construction. Moreover, 
all the prediction methods overestimate the upheaval of ground surface before the jacking machine arriving at the monitoring points. After the arrival of the jacking machine, the results of the proposed method are better than those of the Attewell method [74] and the Wei et al. method [61].

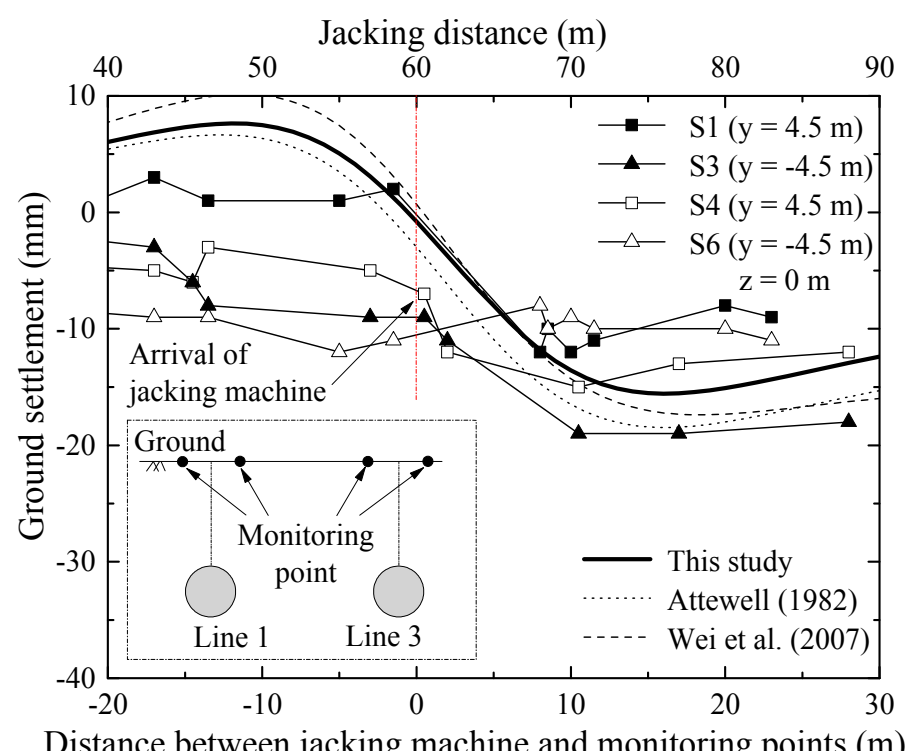

Figure 13. Ground settlements adjacent to Line 1 and Line 4 at ground surface.

Figure 14 shows the variation of ground settlements with the monitoring depth increasing. The predicted results under the ground are consistent with the field data in general. The upheaval of ground in a deeper position is more remarkable. The difference between calculated results and monitored values becomes less at this depth. After the arrival of the jacking machine, the same phenomenon indicates that the calculated ground settlement becomes smaller than those calculated by other two methods is found. Generally, the underground settlements are smaller than the ground surface settlements. In addition, the values of settlements decrease with the increase of monitoring depth.

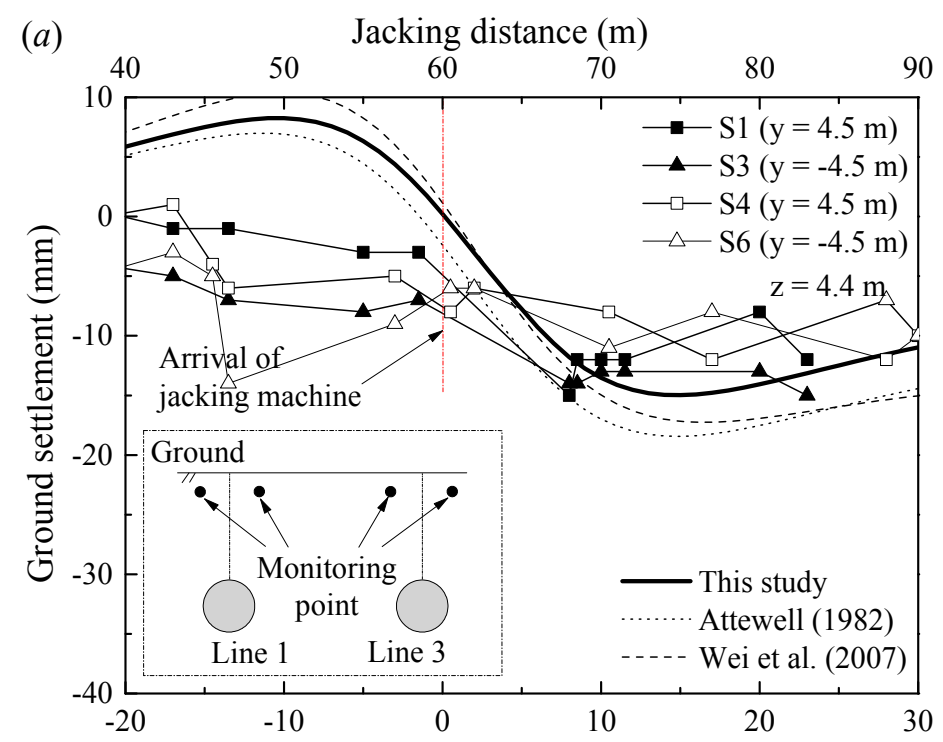

Distance between jacking machine and monitoring points (m)

Figure 14. Cont. 
(b)

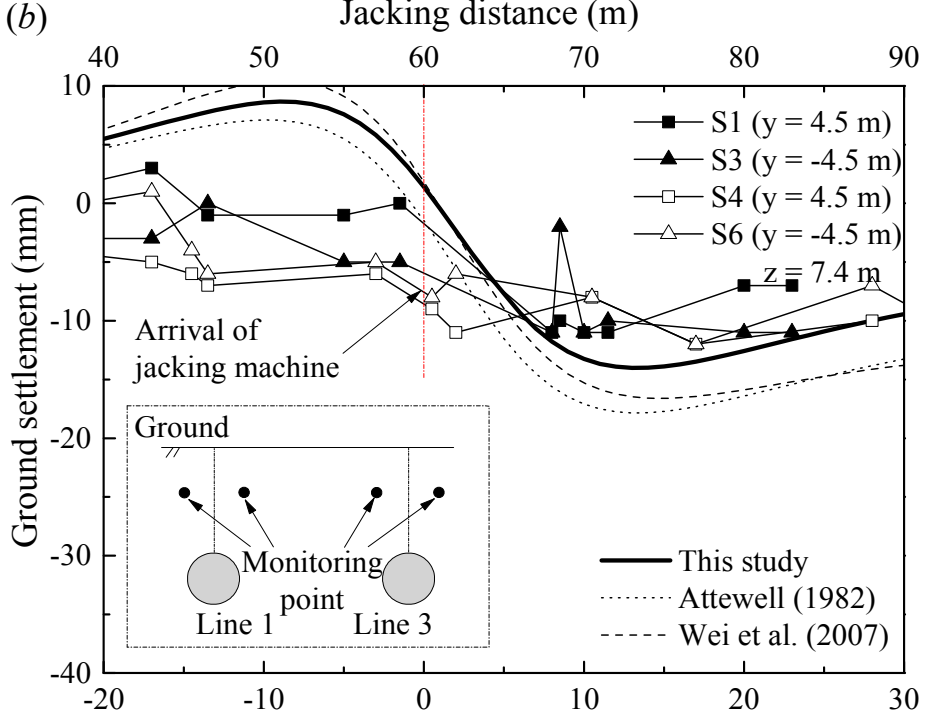

Distance between jacking machine and monitoring points $(\mathrm{m})$

Figure 14. Ground settlements at both sides of pipe-jacking at different depth: (a) $4.4 \mathrm{~m}$, (b) $7.4 \mathrm{~m}$.

Based on above comparisons between calculated results and field observations, the effectiveness of the proposed method for ground settlement prediction was validated. The proposed method can predict the ground settlement caused by the pipe-jacking. The better effectiveness compared to the other two methods can be attributed to the consideration of grouting pressure. The slurry grouting can mitigate the ground loss, so that the prediction effectiveness after the arrival of the jacking machine is better than that of the other methods. However, the calculated upheaval before the arriving of jacking machine is larger than the field value.

Some limitations should be pointed out, which are expected to be improved in future projects. The proposed method is based on the analysis in homogeneous and isotropic condition. However, the geological conditions are always heterogeneous and anisotropic in field cases. The method used in this study was to calculate the average value as the geological parameter, which may attribute to the difference between calculated results and field results. As the field case shows that the ground movement is more irregular in the position close to the tunnel, the prediction may result in a worse result in shallower pipe construction. More case studies are expected to further compare the difference between the proposed method and other existing solutions. In addition, the disturbance caused by adjacent construction needs to be considered for the further improvement of proposed approach.

\section{Conclusions}

This paper presents an approach for calculating the ground deformation. Based on the analysis of jacking process, the effect of grouting pressure on the ground deformation is considered to improve the prediction effectiveness. According to the comparison between calculated results and field observations, the effectiveness of the proposed approach was validated. More specific conclusions are drawn as follows:

(1) The ground deformation caused by bulkhead additive thrust and the friction between jacking machine and the surrounding soils were reanalyzed. The penetration of jacking machine makes surrounding soils and strata in front of the jacking machine under the shearing effect. The shearing disturbance coefficient is employed to evaluate the mitigation effect of shearing behavior on ground deformation.

(2) The grouting process can apply pressure on surrounding soils and mitigate the ground movement. Verruijt's solution is used to calculate the ground movement in sectional direction caused 
by slurry grouting. Then the cumulative ground movement along the jacking direction is determined based on the Boussinesq's solution. The generalized prediction approach is proposed by combining the ground movement caused by bulkhead additive thrust, friction on jacking machine, grouting pressure and ground loss.

(3) A field pipe-jacking construction of water-conveying tunnels was used to validate the prediction approach of ground deformation. As the consideration of grouting pressure, the calculated results after the arrival of jacking machine are consistent with the field data. The robustness is better than the other methods.

Author Contributions: This paper represents a result of collaborative teamwork. J.S.S. provided the concept of this manuscript. Y.-S.X. offered the related data. D.-J.R., developed the concept and wrote the manuscript. A.Z. collaborated the writing work and gave significant comments. A.A. helped to revise the manuscript and figures. The five authors contributed equally to this work.

Funding: This research was funded by the National Basic Research Program of China (973 Program) grant number 2015CB057806. This financial support is gratefully acknowledged.

Conflicts of Interest: The authors declare no conflict of interest.

\section{References}

1. Demeijer, O.; Chen, J.J.; Li, M.G.; Wang, J.H. Influence of passively loaded piles on excavation-induced diaphragm wall displacements and ground settlements. Int. J. Geomech. 2018, 18, 04018052. [CrossRef]

2. Li, M.G.; Chen, J.J.; Wang, J.H.; Zhu, Y.F. Comparative study of construction methods for deep excavations above shield tunnels. Tunn. Undergr. Space Technol. 2018, 71, 329-339. [CrossRef]

3. Peng, J.; Peng, F.L. A GIS-Based evaluation method of underground space resource for urban spatial planning: Part 1 Methodology. Tunn. Undergr. Space Technol. 2018, 74, 82-95. [CrossRef]

4. Qiao, Y.K.; Peng, F.L.; Wang, Y. Monetary valuation of urban underground space: A critical issue for the decision-making of urban underground space development. Land Use Policy 2017, 69, 12-24. [CrossRef]

5. Tan, Y.; Lu, Y. Forensic diagnosis of a leaking accident during excavation. J. Perform. Constr. Facil. 2017, 31, 04017061. [CrossRef]

6. Tan, Y.; Lu, Y.; Wang, D. Deep excavation of the Gate of the Orient in Suzhou stiff clay: Composite earth-retaining systems and dewatering plans. J. Geotech. Geoenviron. Eng. 2018, 144, 05017009. [CrossRef]

7. Ren, D.J.; Shen, S.L.; Cheng, W.C.; Zhang, N.; Wang, Z.F. Geological formation and geo-hazards during subway construction in Guangzhou. Environ. Earth Sci. 2016, 75, 934. [CrossRef]

8. Ren, D.J.; Shen, J.S.; Chai, J.C.; Zhou, A. Analysis of disc cutter failure in shield tunnelling using 3D circular cutting theory. Eng. Fail. Anal. 2018, 90, 23-35. [CrossRef]

9. Shen, S.L.; Xu, Y.S. Numerical evaluation of land subsidence induced by groundwater pumping in Shanghai. Can. Geotech. J. 2011, 48, 1378-1392. [CrossRef]

10. Shen, S.L.; Wu, H.N.; Cui, Y.J.; Yin, Z.Y. Long-term settlement behaviour of metro tunnels in the soft deposits of Shanghai. Tunn. Undergr. Space Technol. 2014, 40, 309-323. [CrossRef]

11. Shen, S.L.; Wang, Z.F.; Cheng, W.C. Estimation of lateral displacement induced by jet grouting in clayey soils. Geotechnique 2017, 67, 621-630. [CrossRef]

12. Shen, S.L.; Wu, Y.X.; Misra, A. Calculation of head difference at two sides of a cut-off barrier during excavation dewatering. Comput. Geotech. 2017, 91, 192-202. [CrossRef]

13. Tan, Y.; Huang, R.; Kang, Z.; Wei, B. Covered semi-top-down excavation of subway station surrounded by closely spaced buildings in downtown Shanghai: Building response. J. Perform. Constr. Facil. 2016, 30, 04016040. [CrossRef]

14. Wu, H.N.; Shen, S.L.; Liao, S.M.; Yin, Z.Y. Longitudinal structural modelling of shield tunnels considering shearing dislocation between segmental rings. Tunn. Undergr. Space Technol. 2015, 50, 317-323. [CrossRef]

15. Wu, H.N.; Shen, S.L.; Yang, J. Identification of tunnel settlement caused by land subsidence in soft deposit of Shanghai. J. Perform. Constr. Facil. 2017, 31, 04017092. [CrossRef]

16. Cheng, W.C.; Ni, J.C.; Shen, S.L. Experimental and analytical modeling of shield segment under cyclic loading. Int. J. Geomech. 2017, 17, 04016146. [CrossRef] 
17. Khazaei, S.; Shimada, H.; Kawai, T.; Yotsumoto, J.; Matsui, K. Monitoring of over cutting area and lubrication distribution in a large slurry pipe jacking operation. Geotech. Geol. Eng. 2006, 24, 735-755. [CrossRef]

18. Liu, X.X.; Shen, S.L.; Xu, Y.S.; Yin, Z.Y. Analytical approach for time-dependent groundwater inflow into shield tunnel face in confined aquifer. Int. J. Numer. Anal. Methods Geomech. 2018, 42, 655-673. [CrossRef]

19. Tan, Y.; Lu, Y. Responses of shallowly buried pipelines to adjacent deep excavations in Shanghai soft ground. J. Pipeline Syst. Eng. Pract. 2018, 9, 05018002. [CrossRef]

20. Wang, F.; Du, Y.J.; Zhou, M.; Zhang, Y.J. Full-scale field study on the effects of installation on buried HDPE pipe. J. Pipeline Syst. Eng. Pract 2016, 7, 05015001. [CrossRef]

21. Zhou, M.; Du, Y.J.; Wang, F.; Martin, D.L. Performance of buried high-density polyethylene pipes. Part I: Peaking deflection during initial backfilling process. Geosynth. Int. 2017, 24, 1-13. [CrossRef]

22. Zhou, M.; Wang, F.; Du, Y.J.; Martin, D.L. Performance of buried high-density polyethylene pipes. Part II: Total deflection of the pipe. Geosynth. Int. 2017, 24, 1-12. [CrossRef]

23. Zhou, M.; Du, Y.J.; Wang, F.; Arulrajah, A.; Horpibulsuk, S. Earth pressures on the trenched HDPE pipes in fine-grained soils during construction phase: Full-scale field trial and finite element modeling. Transp. Geotech. 2017, 12, 56-69. [CrossRef]

24. Almeida e Sousa, J.; Negro, A.; Matos Fernandes, M.; Cardoso, A.S. Three-dimensional nonlinear analyses of a metro tunnel in São Paulo Porous Clay, Brazil. J. Geotech. Geoenviron. Eng. 2010, 137, 376-384. [CrossRef]

25. Lyu, H.M.; Sun, W.J.; Shen, S.L.; Arulrajah, A. Flood risk assessment in metro systems of mega-cities using a GIS-based modeling approach. Sci. Total Environ. 2018, 626, 1012-1025. [CrossRef] [PubMed]

26. Lyu, H.M.; Shen, S.L.; Arulrajah, A. Assessment of geohazards and preventive countermeasures using AHP incorporated with GIS in Lanzhou, China. Sustainability 2018, 10, 304. [CrossRef]

27. Tóth, Á.; Gong, Q.; Zhao, J. Case studies of TBM tunneling performance in rock-soil interface mixed ground. Tunn. Undergr. Space Technol. 2013, 38, 140-150. [CrossRef]

28. Zhang, N.; Shen, J.S.; Zhou, A.; Arulrajah, A. Tunneling induced geohazards in mylonitic rock faults with rich groundwater: A case study in Guangzhou. Tunn. Undergr. Space Technol. 2017, 74, 262-272. [CrossRef]

29. Beckmann, D.; Stein, R.; Fabri, T.; Uhlenbroch, A. CoJack-A new statics method of computing and controlling pipe jacking. Tunn. Undergr. Space Technol. 2007, 22, 587-599. [CrossRef]

30. Elbaz, K.; Shen, J.S.; Cheng, W.C.; Arulrajah, A. Cutter-disc consumption during earth pressure balance tunnelling in mixed strata. Proc. Inst. Civ. Eng. Geotech. Eng. 2018, 171. [CrossRef]

31. Du, Y.J.; Jiang, N.J.; Shen, S.L.; Jin, F. Experimental investigation of influence of acid rain on leaching and hydraulic characteristics of cement-based solidified/stabilized lead contaminated clay. J. Hazard. Mater. 2012, 225-226, 195-201. [CrossRef] [PubMed]

32. Du, Y.J.; Jiang, N.J.; Liu, S.Y.; Jin, F.; Singh, D.N.; Pulppara, A. Engineering properties and microstructural characteristics of cement solidified zinc-contaminated kaolin clay. Can. Geotech. J. 2014, 51, 289-302. [CrossRef]

33. Du, Y.J.; Wei, M.L.; Reddy, K.R.; Liu, Z.P.; Jin, F. Effect of acid rain pH on leaching behavior of cement stabilized lead-contaminated soil. J. Hazard. Mater. 2014, 271, 131-140. [CrossRef] [PubMed]

34. Jin, Y.F.; Yin, Z.Y. ErosLab: A modelling tool for soil tests. Adv. Eng. Softw. 2018, 121, 84-97. [CrossRef]

35. Ong, D.E.L.; Choo, C.S. Back-analysis and finite element modeling of jacking forces in weathered rocks. Tunn. Undergr. Space Technol. 2016, 51, 1-10. [CrossRef]

36. Shen, S.L.; Wang, J.P.; Wu, H.N.; Xu, Y.S.; Ye, G.L.; Yin, Z.Y. Evaluation of hydraulic conductivity for both marine and deltaic deposits based on piezocone testing. Ocean Eng. 2015, 110, 174-182. [CrossRef]

37. Xu, Y.S.; Shen, J.S.; Wu, H.N.; Zhang, N. Risk and impacts on the environment of free-phase biogas in Quaternary deposits along the coastal region of Shanghai. Ocean Eng. 2017, 137, 129-137. [CrossRef]

38. Yen, J.; Shou, K. Numerical simulation for the estimation the jacking force of pipe jacking. Tunn. Undergr. Space Technol. 2015, 49, 218-229. [CrossRef]

39. Jin, Y.F.; Yin, Z.Y.; Wu, Z.X.; Zhou, W.H. Identifying parameters of easily crushable sand and application to offshore pile driving. Ocean Eng. 2018, 154, 416-429. [CrossRef]

40. Jin, Y.F.; Yin, Z.Y.; Wu, Z.X.; Daouadji, A. Numerical modeling of pile penetration in silica sands considering the effect of grain breakage. Finite Elem. Anal. Des. 2018, 144, 15-29. [CrossRef]

41. Leng, J.; Liao, C.C.; Ye, G.L.; Jeng, D.S. Laboratory study for soil structure effect on marine clay response subjected to cyclic loads. Ocean Eng. 2018, 147, 45-50. [CrossRef] 
42. Wu, Y.X.; Shen, S.L.; Yuan, D.J. Characteristics of dewatering induced drawdown curve under blocking effect of retaining wall in aquifer. J. Hydrol. 2016, 539, 554-566. [CrossRef]

43. Wu, Y.X.; Shen, J.S.; Cheng, W.C.; Hino, T. Semi-analytical solution to pumping test data with barrier, wellbore storage, and partial penetration effects. Eng. Geol. 2017, 226, 44-51. [CrossRef]

44. Yin, Z.Y.; Chang, C.S.; Karstunen, M.; Hicher, P.Y. An anisotropic elastic-viscoplastic model for soft clays. Int. J. Solids Struct. 2010, 47, 665-677. [CrossRef]

45. Yin, Z.Y.; Karstunen, M.; Chang, C.S.; Koskinen, M.; Lojander, M. Modeling time-dependent behavior of soft sensitive clay. J. Geotech. Geoenviron. Eng. 2011, 137, 1103-1113. [CrossRef]

46. Yin, Z.Y.; Xu, Q.; Hicher, P.Y. A simple critical state based double-yield-surface model for clay behavior under complex loading. Acta Geotech. 2013, 8, 509-523. [CrossRef]

47. Yin, Z.Y.; Zhao, J.; Hicher, P.Y. A micromechanics-based model for sand-silt mixtures. Int. J. Solids Struct. 2014, 51, 1350-1363. [CrossRef]

48. Yin, Z.Y.; Yin, J.H.; Huang, H.W. Rate-dependent and long-term yield stress and strength of soft Wenzhou marine clay: Experiments and modeling. Mar. Georesour. Geotechnol. 2015, 33, 79-91. [CrossRef]

49. Yin, Z.Y.; Jin, Y.F.; Huang, H.W.; Shen, S.L. Evolutionary polynomial regression based modelling of clay compressibility using an enhanced hybrid real-coded genetic algorithm. Eng. Geol. 2016, 210, 158-167. [CrossRef]

50. Yin, Z.Y.; Jin, Y.F.; Shen, S.L.; Huang, H.W. An efficient optimization method for identifying parameters of soft structured clay by an enhanced genetic algorithm and elastic-viscoplastic model. Acta Geotech. 2017, 12, 849-867. [CrossRef]

51. Yin, Z.Y.; Jin, Y.F.; Shen, J.S.; Hicher, P.Y. Optimization techniques for identifying soil parameters in geotechnical engineering: Comparative study and enhancement. Int. J. Numer. Anal. Methods Geomech. 2018, 42, 70-94. [CrossRef]

52. Milligan, G.W.E.; Norris, P. Pipe-soil interaction during pipe jacking. Proc. Inst. Civ. Eng. Geotech. Eng. 1999, 137, 27-44. [CrossRef]

53. Shou, K.; Yen, J.; Liu, M. On the frictional property of lubricants and its impact on jacking force and soil-pipe interaction of pipe-jacking. Tunn. Undergr. Space Technol. 2010, 25, 469-477. [CrossRef]

54. Wei, G. Establishment of uniform ground movement model for shield tunnels. Chi. J. Geotech. Eng. 2007, 29, 554-559. (In Chinese)

55. Lee, K.M.; Ji, H.W.; Shen, C.K.; Liu, J.H.; Bai, T.H. Ground response to the construction of Shanghai metro tunnel-line 2. Soils Found. 1999, 39, 113-134. [CrossRef]

56. Ren, D.J.; Shen, S.L.; Arulrajah, A.; Wu, H.N. Evaluation of ground loss ratio with moving trajectories induced in DOT tunnelling. Can. Geotech. J. 2018, 55, 894-902. [CrossRef]

57. Wei, G. Prediction of ground deformation induced by shield tunneling construction. Chin. J. Rock Mech. Eng. 2009, 28, 418-424. (In Chinese)

58. Sagaseta, C. Analysis of undrained soil deformation due to ground loss. Geotechnique 1987, 37, 301-320. [CrossRef]

59. Loganathan, N.; Poulos, H.G. Analytical prediction for tunneling-induced ground movement in clays. J. Geotech. Geoenviron. Eng. 1998, 124, 846-856. [CrossRef]

60. Liao, S.; Yu, Y.; Peng, F. Numerical analysis of shield tunneling construction through adjacent objects. Rock Soil Mech. 2004, 25, 223-226.

61. Wei, G.; Xu, R.Q.; Xiao, J.; Yu, W.J.; Li, W.X. Analysis of Ground Deformation Caused by Pipe-jacking Construction. China Munic. Eng. 2002, 4, 27-29. (In Chinese)

62. Zhang, D.; Fang, Q.; Lou, H. Grouting techniques for the unfavorable geological conditions of Xiang'an subsea tunnel in China. J. Rock Mech. Geotech. Eng. 2014, 6, 438-446. [CrossRef]

63. Li, F.; Fang, K.; Li, H. Application of ANSYS 3D FEM in studies of surface deformation caused by pipe jacking. Wuhan Univ. J. Nat. Sci. 2007, 12, 633-637. [CrossRef]

64. Shimada, H.; Khazaei, S.; Matsui, K. Small diameter tunnel excavation method using slurry pipe-jacking. Geotech. Geol. Eng. 2004, 22, 161-186. [CrossRef]

65. Shimada, H.; Sasaoka, T.; Khazaei, S.; Yoshida, Y.; Matsui, K. Performance of mortar and chemical grout injection into surrounding soil when slurry pipe-jacking method is used. Geotech. Geol. Eng. 2006, 24, 57-77. [CrossRef] 
66. Kasper, T.; Meschke, G. On the influence of face pressure, grouting pressure and TBM design in soft ground tunnelling. Tunn. Undergr. Space Technol. 2006, 21, 160-171. [CrossRef]

67. Verruijt, A. Deformation of an elastic half plane with a circular cavity. Int. J. Solids Struct. 1998, 35, $2795-2804$. [CrossRef]

68. Wang, Z.F.; Shen, J.S.; Cheng, W.C. Simple method to predict ground displacements caused by installing horizontal jet-grouting columns. Math. Probl. Eng. 2018, 1897394. [CrossRef]

69. Mindlin, R.D. Force at a point in the interior of a semi-infinite solid. Physics 1936, 7, 195-202. [CrossRef]

70. Lee, K.M.; Rowe, R.K.; Lo, K.Y. Subsidence owing to tunnelling. I. Estimating the gap parameter. Can. Geotech. J. 1992, 29, 929-940. [CrossRef]

71. Shen, S.L.; Cui, Q.L.; Ho, C.E.; Xu, Y.S. Ground response to multiple parallel microtunneling operations in cemented silty clay and sand. J. Geotech. Geoenviron. Eng. 2016, 142, 04016001. [CrossRef]

72. Ye, G.L.; Ye, B. Investigation of the overconsolidation and structural behavior of Shanghai clays by element testing and constitutive modeling. Undergr. Space 2016, 1, 62-77. [CrossRef]

73. Likitlersuang, S.; Teachavorasinskun, S.; Surarak, C.; Oh, E.; Balasubramaniam, A. Small strain stiffness and stiffness degradation curve of bangkok clays. Soils Found. 2013, 53, 498-509. [CrossRef]

74. Attewell, P.B. Predicting the dynamics of ground settlement and its derivatives caused by tunnelling in soil. Ground Eng. 1982, 15, 36.

(c) 2018 by the authors. Licensee MDPI, Basel, Switzerland. This article is an open access article distributed under the terms and conditions of the Creative Commons Attribution (CC BY) license (http://creativecommons.org/licenses/by/4.0/). 